\title{
Legal Protection of Indonesian Migrant Workers: International Law, National Regulations and Contemporary Problems
}

\author{
Darminto Hartono ${ }^{1, *}$ and Indranila Kustarini Samsuria ${ }^{2}$ \\ ${ }^{1}$ Faculty of Law, Universitas Diponegoro, Semarang, Indonesia \\ ${ }^{2}$ Faculty of Medicine, Diponegoro University, Semarang, Indonesia
}

\begin{abstract}
The research aims to focus on how to conduct an investigation of the regulations for the protections of Indonesian Migrant Workers (IMW) and what efforts are needed by the Indonesian government in addressing the problems for application of regulation. The method uses descriptive research with a qualitative approach through the normative juridical method and data analysis method. With the revised regulation videlicet Law No 18 of 2017 , the Indonesian government will not only serve applicant of Indonesian migrant workers but also to their families. Furthermore, it will improve the quality of migrant workers along with protecting and providing safety for their families. The findings showed that Indonesian migrant workers as a legal subject have the rights to be protected and to oblige the requirements which is set by the Indonesian government as sending state and the government of destination state. Legal protection of Indonesian migrant workers in overseas required binding protection which is provided by the state.
\end{abstract}

Keywords: Indonesia, migrant worker, legal protection, overseas.

\section{INTRODUCTION}

To achieve a certain goal, a state often holds cooperation or relations with other states. In this partnership, each state must have the intent and purpose in accordance with its national interests, so that each state has their own interests, and occurrences of the conflicts of interest arising is unavoidable in the society (Soekotjo \& Aninditya, 2018; Hasanudin et al., 2020). In this globalization era, the right of human life has been gaining a lot of attention in the international community. The regulation of the mankind right to life is set in the provisions internationally and nationally. Nowadays, one of the programs on the human rights to life is the Indonesian Migrant Workers in overseas which is loaded with many problems (Rother, 2018; Adnyana et al., 2020; Hardiwinoto, 2014).

In Asia, women workers from Indonesia, Laos and Cambodia migrate to work in Malaysia, Burma until Thailand to become migrant workers (Romero, 2018; ILO, 2013; Nurwulandari et al., 2019; Panam et al., 2004). The Middle East is also a destination state for Indonesian migrant workers to migrate and seek decent jobs in the United Emirates Arab (Romero, 2018; Human Rights Watch, 2014). The big interests of Indonesian Migrant Workers abroad on the one hand have a positive impact in addressing the limitations of employment in domesticstate, but on the other hand

*Address correspondence to this author at the Faculty of Law, Universitas Diponegoro, Semarang, Jl. Prof. Soedarto, Tembalang, Semarang, Central Java 50275, Indonesia; Tel: +62-2476918201; Fax: +62-247691820;

E-mail: darmintohartono.undip@gmail.com also have a negative impact in the form of risk the possibility of inhumane treatment of migrant workers. This risk is quite reasonable considering almost $70 \%$ of migrant workers are working in the informal sector, especially as an assistant households and $90 \%$ of them are women (Hardiwinoto et al., 2018).

Indonesia as a sending state of Indonesian Migrant Workers would have to renew the laws that govern and protect migrant workers abroad. In Law no. 39/2004regarding the Placement and Protection of Indonesian Workers Overseas does not guarantee the entire protection of Indonesian Workers. On the implementation, the Act already covers for Indonesian workers needed but considered that there are still shortcomings in the implementation in this field. Therefore, the government renewed the arrangement by issuing Law No. 18/2017 on the Protection of Indonesian Migrant Workers, as a manifestation of the needs of migrant workers especially those working overseas in order to work in a safe, convenient, fast, accurate, and inexpensive. Indonesian Migrant Workers Protection Agency along with government officials both central and local levels try to overcome the issues that will arise in the implementation of the new legislation. There is a tendency emerging issues that must be addressed, namely: how is the form of legal protection for Indonesian migrant workers by law No. 18/2017 and what efforts are needed by the Indonesian Government to faces the obstacles of implementing the new regulation.

\section{LITERATURE REVIEW}

The rights to work and rights at work are Human Rights. Protection and fulfillment of these rights giving 
importance to the need of a decent standard of living (Muhtaj, 2009). The Indonesian Constitution mentioned several articles that explain on these rights. Article 27 (2) stated that "every citizen has the right to work and a decent living for humanity." Furthermore, Article 28C paragraph (1) stated that "everyone has the right to develop themselves through the fulfillment of basic needs, and is entitled to education and to benefit from science and technology, art and culture, in order to improve the quality of life and for the welfare of mankind." In addition, Article 28D stated that everyone has the right to recognition, security, protection and legal certainty and equal treatment before the law, and to work and to receive remuneration and fair and proper treatment in the employment relationship. These articles contained the right to work and rights at work.

In international law, for the fulfillment of these rights by the destination state, the government should launch a diplomatic approach so that migrant workers' rights continue to be protected and prioritized as specified in International Covenant on Civil and Political Rights (ICCPR), International Covenant on Economic, Social and Cultural Rights (ICESCR), and Committee on the Elimination of Racial Discrimination (CERD), and Convention on the Elimination of All Forms of Discrimination Against Women (CEDAW). At least, there are fourteen kinds of migrant workers' rights on this conventions, such as the right to life (ICCPR Article 6; Migrant Workers Convention Article 9); freedom from discrimination (ICCPR articles 2 and 26); freedom from torture or inhuman or degrading treatment of other cruel, inhuman or degrading treatment (ICCPR Article 7; Migrant Workers Convention Article 10); recognition as a person before the law (ICCPR Article 16; Migrant Workers Convention Article 24); free from slavery, servitude and compulsory labor (ICCPR Article 8; Migrant Workers Convention Article 11 of the ILO Forced Labor Convention; ILO Convention on the Abolition of Forced Labor); The right to liberty and security of person (ICCPR Article 91; Migrant Workers Convention Article 16.1); The right to health (ICESCR Article 12; CERD Article 5 (e) (iv); CEDAW Articles 12 and 14 (b); CRC Articles 24 and 25; Migrant Workers Convention Article 28 (which refers to a special right to receive health care emergency) ); The right to education (ICESCR Articles 13 and 14; CRC Articles 28 and 29; ICERD Article 5 (e) (v); Migrant Workers Convention Article 30); The right to adequate housing (ICESCR Article 11; CEDAW Article 14 (2); CRC Article 16 (1) and 27 (3); ICERD Article 5 (e) (iii)); The right to adequate food and water (ICESCR Article 11; CRC Article 24 (2) (c); CEDAW Article 14 (2)); Freedom of thought, religion and belief (ICCPR Article 18, 19; Migrant Workers Convention 12 (1)); Freedom of movement (Migrant Workers Convention Article 8; ICCPR Article 12); The right to personal affairs/privacy (ICCPR Article 17; Migrant Workers Convention Article 14); Deprived of their right to property (Migrant Workers Convention Article 15).

With the Constitution as the source of law and basic constitutional of the state and the number of human resources in Indonesia, the Government is obliged to provide jobs with amenities. Indonesia has cooperated with other countries to take the advantage of human resources by sending Indonesian citizens to work in overseas, it called International Migrant Workers. According to Suharto (2016), an internal migrant worker (in the state) is a person who migrates from place of origin to work elsewhere is still included in the area of Indonesia, while international migrants (overseas) are those who left their homeland to works in other states. In Law No. 18/2017 Article 1 paragraph 2 stated, Indonesian Migrant Workers is every Indonesian citizens who will, are or have been doing the job for a wage outside the territory of the Republic of Indonesia. While at the number 5 mentioned that the Protection of Indonesian Migrant Workers is doing every efforts to protect the interests of applicant Indonesian Migrant Workers and their families in realizing the assurance of its rights in all activities before, during and after working in the legal, economic and social aspects.

Globally, the International Labor Organization (ILO) has been working on the protection of migrant workers since its formation in 1919 as part of its constitutional mandate. The International Labor Organization (ILO)and the United Nations (UN) also formulated international conventions on migrant workers' rights protection. Reviews these conventions in effect of global set of standards and principled ideas for the protection of migrant workers' rights. The International Labor Organization (ILO) has adopted two conventions that deal specifically with labor migration. First, the International Labor Organization (ILO) Convention 97 (Migration for Employment Convention) was approved in 1949 and its core principle is the obligation on ratifying states to implement equal treatment between migrant workers and workers of Reviews their own nationals. States should aim to achieve this goal by signing bilateral agreements that specify conditions and recruitment procedures for cross-border employment (Auethavornpipat, 2017; Kuptsch \& Martin, 2011). Second, International Labor Organization (ILO) 
Convention 143 (Migrant Workers Convention) was Adopted in 1975 stressing the protection of migrants in exploitative situations as well as equal opportunity and the integration of settled migrants. It bids ratifying countries to Eliminate clandestine movement and employment of migrant workers. Then in 1990, the United Nations (UN) General Assembly passed the International Convention on the Protection of the Rights of All Migrant Workers and Members of Their Families. This United Nations (UN) Convention covers all types of migrants and also extends the protection to family members. It took 13 years before it came into effect in 2003 when the minimum number of 20 ratifying states was met (Auethavornpipat, 2017; Piper \& Iredale, 2003).

In the International Labor Organization (ILO) Convention No. 97 on Migration for Employment Convention which is the main reference definition of migrant worker stated that "a person who migrates from one state to another with a view to being employed otherwise than his own account and includes any person regularly admitted as a migrant for employment". The point is, a person who migrates from one state to another, with the intention to work for the fulfillment of its right to be called by migrant workers. Meanwhile, according to the International Labor Organization (ILO, 2013) and the International Organization for Migration (IOM, 1009, 12), a migrant domestic worker is someone who is moving to another state or region to life and social conditions are more viable and improve prospects for themselves or family, work in providing services for the workers or for the household (Islam \& Cojocaru, 2016).

With the Indonesian migrant workers abroad, the Indonesian government is obliged to continue to protect its citizens. Indonesia as the Indonesian Migrant Workers Sending State, would have to renew the regulation that govern and protect migrant workers in overseas. In Law No. 39/2004 on the Placement and Protection of Indonesian Workers in Overseas does not guarantee the entire protection of Indonesian Workers. On the implementation, the Act already covers the need for Indonesian workers but considered there are still shortcomings in the implementation in the field. Thus, the Indonesian government through Law No. 18/2017 revise the regulation on the Protection of Indonesian Migrant Workers. The regulation is based on the United Nations Convention on the Protection of the Rights of All Migrant Workers and Members of their Families which prioritize on the rights of Indonesian migrant workers' protection and also their families.
Protection of migrant workers in the Law No. $18 / 2017$ prioritizing the citizens responsibility which supported by the Indonesian Government and the Placement Company of Indonesian Migrant Workers. It is also the basis for the authority of the central government's role in dividing protect migrant workers with the region/town and village officials. According to the law, the applicant Indonesian migrant workers should be assisted and educated since being in the region, not just in the center. Protection of migrant workers are also divided into 3 (three) stages in accordance with Article 7 of the Act, namely protection before work; protection during the work; and protection after work. Protection before work is divided into two, namely the protection of the administrative and technical protection. According to Article 8, paragraph (2), protection of administrative is the prioritizing protection for checks and determination of the validity of documents applicant migrant workers. Whereas in Article 8 paragraph (3) mentioned some technical protection refers to strengthening the role of one-stop service for placement and protection of applicant Indonesian migrant workers. Furthermore, the applicant migrant workers improved education and job training which is held according to the field of work as well as promoting and disseminating the provision of information of social security.

While protection during work, according to Article 21, the government through Indonesian Migrant Workers Protection Agency started recording and registering migrant workers in overseas as a form of monitoring and evaluation of the employer, job and conditions of migrant workers. In addition, the government is not hands-off according to providing the consular services and settlement of labor cases. The Indonesian government will oversee such cases ranging from mentoring, mediation, to advocacy. At the same time, after work term is focused on the protection after completion of the rights of Indonesian migrant workers who have not been fulfilled, rehabilitation and social reintegration, as well as the facilitation provided by the government-facilitated if the migrant worker illness and death up to the return to the region of origin.

In Law No. 18/2017 also mentioned the legal, social and economic protections. First, legal protection is explained in Article 31, 32 and 33 which show the capacity of national governments to protect Indonesian migrant workers in overseas. The national government in its role must have a valid legality with the Destination States with the Agreement regarding the placement of Indonesian migrant workers in the destination states. In 
addition, the national government could stop and/or prohibit the placement of Indonesian migrant workers in certain states with regard suggestions and considerations by Representative of Republic of Indonesian, ministry/institutions, placement agent of Indonesian Migrant Workers and society. Secondly, social protection under Article 34 describes the importance of improving the quality of education and vocational training will be done by the applicant migrant worker. In addition, the government also tightened placement agent of Indonesian Migrant Workers registration in order to increase its role in protecting the applicant migrant workers. Thirdly, protection of financial economics organizes migrant workers provided for in Article 35 and 36 . In the article explained that the central and local government authorities shall maintain appropriate remittance through banking institutions or non-bank financial institutions in the state and the state of destination state. In addition, financial education and entrepreneurship of migrant workers and families is also facilitated by the government.

\section{RESEARCH METHOD}

The research was conducted to focus on the investigation of legal protection of Indonesian Migrant Workers in Overseas Based on Law No. 18/2017 which is legally binding protection provided by the State with the guidance of the regulation. This study uses data analysis approaches and normative juridical method. It uses descriptive analysis method by using literature, documentary studies and field research related to the primary substance of this study. After the data has been collected, the next process is to identify, clarify and analyze systematically. Finally, all research results are presented in a compiled final report.

Specifically, the study analyzes the rules in various international covenants on the protection of migrants, particularly the International Covenant on Civil and Political Rights (ICCPR), the International Covenant on Economic, Social and Cultural Rights (ICESCR), and the Committee on the Elimination of Racial Discrimination (CERD), and Convention on the Elimination of All Forms of Discrimination Against Women (CEDAW). Several regulations regarding migrant workers at the national level, especially Law No. 18/2017 on Protection of Indonesian Migrant Workers, are also used as a reference in this study to analyze how national regulations are able to accommodate contemporary demands regarding the protection of Indonesian migrants and address emerging problems.

\section{RESULTS}

In 2012, the International Labor Organization (ILO) estimates that there are $\mathbf{2 0 . 9}$ million victims of forced labor or labor in the worldwide and household workers is one that affects the sector of a state's economy. Household workers often sacrifice themselves to feed their families, despite the importance of the protection they are exploited by all sorts of ways (Varia, 2007). Violence received by the workers, was recorded in a document of The Human Rights Watch in 2007 which states that physical violence including the beating received by workers using tools such as belts, shoes, household appliances, etc.; head banged against the wall, and burn the skin using a board or chemicals. In some cases, physical violence can lead to blindness, disability and even death. One of them Indonesian migrant workers were beaten to death and found 200 bruises on her body, such as the former punches, kicks, burns from chemicals (Smales, 2010; Moyce \& Schenker, 2018; Wardhani \& Christia, 2020). Singapore and Malaysia are two states that receive the most of Indonesian migrant workers (Farida et al., 2019). The low wages that is given to workers, one of reason to the states recruit more workers from Indonesia. The workers employed in the construction field, the company, the service sector and as household workers. The employer can also control the workers freely and repatriate workers they do not want at any time without waiting for completion of contract. In addition, job mobility and worker deportation numbers become barriers to employment and access to justice to migrant workers (Bal \& Gerard, 2018).

Although the Government of Indonesia already has regulations governing the protection of Indonesian migrant workers abroad, the reality shows that there are still many problems that become obstacles for the Indonesian government to implement protection for Indonesian migrant workers in accordance with the law (Palmer \& Missbach, 2019). Prior to departure, many of the placement agent of Indonesian Migrant Workers who does not have a license from the government to recruit Indonesian migrant workers are recruiting illegally. placement agent of Indonesian Migrant Workers does recruit illegal Indonesian migrant workers, including sometimes does not even care about the safety of the workers so that they are free to recruit applicant Indonesian migrant workers, including the recruitment of minors, unskilled workers and 
falsification of documents to obtain profit. As a result, Indonesian migrant workers who are recruited illegally by placement agent of Indonesian Migrant Workers could not receive the rights which was given before departure to destination state.

The Indonesian migrant workers whom departing illegally, are often under difficulty while working in overseas. Violence and oppression that are committed by the employer is not seldom received by workers at work. Those who work abroad sometimes can not escape or return to Indonesia because the important documents retained by the employer or placement agent of Indonesian Migrant Workers. Moreover, the high salaries that has to be paid, interrupted by placement agent of Indonesian Migrant Workers with the unmatch amount with the regulation and sometimes none at all on salaries. These problems not only affect the migrant workers, but also to the families in the homeland. Indonesian migrant workers'families often report lost contact with family members who working in overseas. The breakdown of communication on migrant workers make families worried because of the many cases of abuse to migrant workers and slow or even lack of information for the family if something happens to migrant workers in overseas (Waridin et al., 2020).

The government also regulates the protection of Indonesian migrant workers when they return home because of many complaints are often received. Start of the repatriation of inadequate facilities, robbery of salary, up to fall into the trap of sexual harassment brokers and being a victim of human trafficking in overseas. Oftentimes, the government has received complaints in the form of defects or injuries suffered by workers when returning from overseas. In Law $18 / 2017$, the Government attach great importance to the role of Integrated Services One-Stop Placement and Protection of Indonesian Migrant Workers, which is a system of providing information, eligibility and handling problems of Indonesian Migrant Workers integrated in the public service that is cheap, easy and fast without any discrimination. Other than that, the government also opened the Integrated Employment Information System in an effort to protect the Indonesian migrant workers in overseas. Integrated Employment Information System is a unitary component consisting of institutions, human resources, hardware, software, and the substance is related to one another in the working mechanism of data and the integrating information of man power management.
The problems that occur at any time, be settled by the government as a form of efforts to protect Indonesian migrant workers. In the Law of Protection of Indonesian Migrant Workers, regulating protection begins before work, during work until after work. There are at least eight (8) types of protection under Article 21 in the the Law of Protection of Indonesian Migrant Workers to be provided by the Government of Indonesia to the Indonesian Migrant Workers, namely data collection and registration by Manpower attache; monitoring and evaluation of employers and job conditions; facilitating the fulfillment on the rights of migrant workers; facilitating the settlement on labor cases; settling for consular services; facilitation, mediation, advocacy, and the provision of legal assistance in the facilitating services of an advocate; development of migrant workers; and facilitation of repatriation (Jaringan Buruh Migran, 2018).

The government also regulates the placement of Indonesian migrant workers shall be detailed in Article 49 until Article 57. In Article 49 stipulated clearly the subject of implementing Indonesian Migrant Workers placement consisting of the Agency, placement agent of Indonesian Migrant Workers, and the placement company of Indonesia's Migrant Workers of the interests for company itself. Whereas in Article 51, the government sought to protect migrant workers through regulation of the License for placement agent of Indonesian Migrant Workers that issued by the Ministry of Labor. To implement the placement protection of Indonesian migrant workers, the Government of the Republic of Indonesia issued Government Regulation No. 10/2020 on Procedures for Placement of Indonesian Migrant Workers by Indonesian Migrant Workers Protection Agency. Indonesian Migrant Workers Protection Agency is the government agency tasked non-ministry agency as implementing the policy in the service and protection of Indonesian migrant workers in an integrated manner.

In addition, for the protection of migrant workers by the central government under Article 39 of the Central Government, Article 40 of the Provincial Government, Article 41 of the Local Government of Region/City, Article 42 of the village government. Each role of government has the different duty and responsibility. The Central Government has the duty and responsibility of arranging the recruitment process ranging from the protection of migrant workers, the delivery, fulfillment of the right to take care of regulation the License for placement agent of Indonesian Migrant Workers. While the provincial government, focus on 
education and job training pre-departure. In addition, the provincial government has an obligation to report periodically of placement agent of Indonesian Migrant Workers to the central government. Duties and obligations of Local Government of Region/City is dissimilar, i.e. disseminate information and requests migrant workers to local society. In addition Regional/City Government must also reintegration for social and economic to workers and their families. While the village government has the duty and the responsibility to verify the data potential migrants as well as to empower migrant workers.

Placement agent of Indonesian Migrant Workers role in the Law of Protection of Indonesian Migrant Workers does not have a dominant role as in the previous act. As well as in this Act, placement agent of Indonesian Migrant Workershas limited role and activities. The only placement agent of Indonesian Migrant Workersthat may conduct placement activities of Indonesian migrant workers is an incorporated company. A company should only conduct in finding a job opportunities, locate and resolve the issue in accordance with Article 52 of the Law on Protection of Indonesian Migrant Workers. This is in accordance with the substance of the International Convention on the Protection of the Rights of All Migrant Workers and Members of Their Families on 1990 which reduces the private sector's role in the recruitment of Indonesian Migrant Workers.

The placement agent of Indonesian Migrant Workers with Indonesian Migrant Workers Protection Agency team up to protect and provide the Indonesian Migrant Workers working overseas. The government does not allow placement agent of Indonesian Migrant Workers put Indonesian Migrant Workers to the destination state where there is no Agreement with the Government of Indonesia. These states which has an Agreement with the Government of Indonesia are Malaysia, Taiwan, Hong Kong, Singapore, Saudi Arabia, Brunei Darussalam, South Korea, United Arab Emirates, Qatar, Oman, Kuwait, Italy, Turkey, Japan, United States of America, New Zealand, Maldives, Zambia , Germany, the Solomon Islands, Gabon, Denmark, Brazil, Bahrain, France and others. Aside from the problems of protection by the government of Indonesia which often constrained, the destination state of Indonesian Migrant Workers sometime does not applies 14 implementation of the protection of migrant workers that set out in the International Convention on the Protection of the Rights of All Migrant Workers and Members of Their Families in
1990, the International Covenant on Civil and Political Rights or ICCPR, Convention on Elimination of All Forms of Discrimination Against Women or CEDAW, the International Convention on the Elimination of All Forms of Racial Discrimination or ICERD, and the International Covenant on Economic, Social and Cultural Rights or ICESCR.

\section{CONCLUSION}

The conclusion was drawn by the basic rights of every citizen to have the right for education and a decent job with a salary commensurate with their skills and professionalism. As in case the migrant workers, they are entitled to protection from the government and also the protection of the government of placement state. The results demonstrated that the government has a function and duty to provide legal protection for Indonesian migrant workers which required to lead and control to be decent and understand better the legal regulation concerning the protection between the government and Indonesian Migrant Workers. Implementation of the legal protection of Indonesian migrant workers still has not fulfilling expectations. Therefore, the Government of Indonesia revised the regulation wit Law No. 18/2017 on the Protection of Indonesian Migrant Workers.

The results would imply that by means of the new act, the Government not only protect migrant workers but also their families in accordance with the provisions of the ratified International Labor Organization Conventions and the International Convention on the Protection of the Rights of All Migrant Workers and Members of Their Families in 1990. In the practical implementations of the new act, the Indonesian government through the representatives of the Republic of Indonesia and the Manpower Attaché must adjust labor agreement documents in accordance with international human rights standards and ensure every placement and extended in accordance with the migrant workers' document. To dispel the illegal placement of Indonesian migrant workers by placement agent of Indonesian Migrant Workers, the government has to ensure that the job vacancy is already verified both by Indonesia as the sending state or the destination state.

\section{REFERENCES}

Adnyana, I.M., Hasanudin,, \& Nurwulandari, A. (2020). Empirical examination of intersectoral linkages between tourism and regional economy by using the social accounting matrix. International Journal of Economics and Business Administration, 8(1), 425-432. https://doi.org/10.35808/ijeba/436 
Auethavornpipat, R. (2017). Assessing regional cooperation: ASEAN states, migrant worker rights and norm socialization in Southeast Asia. Global Change, Peace \& Security, 29(2), 129-143. https://doi.org/10.1080/14781158.2017.1293021

Bal, C. S., \& Gerard, K. (2018). ASEAN's governance of migrant worker rights. Third World Quarterly, 39(4), 799-819. https://doi.org/10.1080/01436597.2017.1387478

Farida, E., Rahayu, \& Wijaningsih, D. (2019). Politics and legal philosophy of indonesian migrant worker protection: Case study in Malaysia. International Journal of Scientific and Technology Research 8(11), 2002-2004

Hardiwinoto, S. (2014). Teaching Materials of International Law. Semarang: Diponegoro University.

Hasanudin,, Nurwulandari, A., Adnyana, I.M., \& Loviana, N. (2020). The effect of ownership and financial performance on firvalue of oil and gas mining companies in Indonesia. International Journal of Energy Economics and Policy, 10(5), 103-109. https://doi.org/10.32479/ijeep.9567

Human Rights Watch. (2014). "I Already Bought You" Abuse and Exploitation of Female Migrant Domestic Workers in the United Arab Emirates. Available: https://www.hrw.org/sites/default/files/reports/uae1014_forUp load.pdf. Accessed on March 23, 2021.

International Labour Office. (2013). Domestic workers across the world: Global and regional statistics and the extent of legal protection. Geneva: International Labour Office.

Islam, M. R., \& Cojocaru, S. (2016). Migrant domestic workers in Asia: Transnational variations and policy concerns. International Migration, 54(1), 48-63. https://doi.org/10.1111/imig.12201

Jaringan Buruh Migran. (2018). Buku Saku Memahami Undang Undang Perlindungan Pekerja Migran Indonesia. Jakarta: Jaringan Buruh Migran. Retrived from: https://issuu.com/jaringan-buruhmigran/docs/buku_saku_jbm.

Kuptsch, C., \& Martin, P. (2011). Low-skilled labour migration. Global Migration Governance, 34-59. https://doi.org/10.1093/acprof:oso/9780199600458.003.0002

Moyce, S. C., \& Schenker, M. (2018). Migrant workers and their occupational health and safety. Annual review of public health, 39, 351-365. https://doi.org/10.1146/annurev-publhealth-040617-013714

Muhtaj, E. (2009). Dimensions of Human Rights: Describing Economic, Social and Cultural Rights. Jakarta: RajaGrafindo Persada.

Nurwulandari, A., Adnyana, I.M., \& Hasanudin. (2019). Did interregional trade agreements bring mutual benefits? An empirical scheme of Indonesian commodity exports in
Asean-China Free Trade Area. International Journal of Financial Research, 10(6), 241-249. https://doi.org/10.5430/ijfr.v10n6p241

Palmer, W., \& Missbach, A. (2019). Enforcing labour rights of irregular migrants in Indonesia. Third World Quarterly, 40(5), 908-925. https://doi.org/10.1080/01436597.2018.1522586

Panam, A., Zaw, K. M. K., Caouette, T., \& Punpuing, S. (2004). Migrant Domestic Workers: From Burma to Thailand.

Piper, N., \& Iredale, R. (2003, October). Identification of the Obstacles to the Signing and Ratification of the UN Convention on the Protection of the Rights of All Migrant Workers. UNESCO Series of Country Reports on the Ratification of the UN Convention on Migrants, 1-68.

Romero, M. (2018). Reflections on globalized care chains and migrant women workers. Critical Sociology, 44(7-8), 11791189. https://doi.org/10.1177/08969205177488497

Rother, S. (2018). ASEAN Forum on Migrant Labour: A space for civil society in migration governance at the regional level? Asia Pacific Viewpoint, 59(1), 107-118. https://doi.org/10.1111/apv.12181

Smales, P. (2010). The right to Unite: $A$ handbook on domestic worker rights across Asia. Asia Pacific Forum on women, law and development (APWLD).

Soekotjo, H., \& Aninditya, G. K. P. (2018). Legal Protection of Indonesian Workers Abroad (Country Practice: Saudi Arabia, Hong Kong, Japan, Korea, Malaysia, Singapore and Taiwan) (The Legal Protection of Indonesian Workers Abroad (Saudi Arabia, Hong Kong, Japan, Korea, Malaysia, Singapore and Taiwan). Semarang: Diponegoro University Press

Suharto, E. (2016). Permasalahan Pekerja Migran: Perspektif Pekerjaan Sosial. Available: http://policy.hu./suharto/modul_a/makindo_35.htm. Accessed on March 23, 2021.

Varia, N. (2007). Globalization Comes Home: Protecting Migrant Domestic Workers' Rights. Washington, DC: Human Rights Watch.

Wardhani, L.T.A.L., \& Christia, A.M. (2020). The politics of law in prohibiting physical violence for domestic workers in the largest economy in Southeast. Academic Journal of Interdisciplinary Studies 9(4), 55-61. https://doi.org/10.36941/ajis-2020-0061

Waridin, W., Dwiyanto, B.M., Saraswati, R., \& Mafruhah, I. (2020). Formulation of problem-solving design for indonesian informal sector migrant workers towards post-placement independence: Case study in Malaysia. Research in World Economy 11(1), 115-122. https://doi.org/10.5430/rwe.v11n1p115

\section{https://doi.org/10.6000/1929-4409.2021.10.101}

(C) 2021 Hartono and Samsuria; Licensee Lifescience Global.

This is an open access article licensed under the terms of the Creative Commons Attribution Non-Commercial License (http://creativecommons.org/licenses/by-nc/3.0/) which permits unrestricted, non-commercial use, distribution and reproduction in any medium, provided the work is properly cited. 